\title{
Eastern Europe: Quo Vadis?
}

One of the main attributes of conservative economics is its emphasis on institutional evolution, spontaneous orders and gradual human adaptation. No economies take 'kindly' to revolutions, upheavals or shocks. 'Shocking' policy measures and 'overnight' state interventions are rightly abhorred and feared by most responsible economists and politicians. Yet, most of their accumulated experience and wisdom about economies, economics and politics was abandoned with gusto in Eastern Europe and Russia. Their common sense and centuries-old intuitions have yielded to ex-communist battle cries for revolution, radical reforms, overnight liberalizations and shock therapies: 'Better tomorrows are [as always] just around the corner!'

The truth is that transformation reforms in Russia and Eastern Europe are not proceeding well and their future prospects are dismal. They have already stalled, most obviously in Poland and Russia. Reform processes continue to be dominated from the top by decrees of governmental ex-communiststurned-capitalists. They and their protégés have clearly profited from their own 'get-rich-quick' schemes of 'paper capitalism' which provided them with a way out through the fast, chaotic and cashonly-based acquisitions of state properties. But their 'quick and dirty' approach is totally unsuitable for the production- and productivity-deficient economies and their increasingly impoverished citizenry.

History will judge harshly those who supported or financed their own political or economical goals at the expense of other people's economies, societies and cultures.

As a result of 'shock therapy', East European and Russian economies are hovering on the brink of collapse, their societies are in chaos, riddled with

\footnotetext{
IOS Press

Human Systems Management 12 (1993) 259-264
}

crime, corruption and bribery, and the once proud national cultures are all but destroyed in the name of meaningless 'Europeanism'. Only the nouveau riche layers of ex-communists, ex-aparatchiks, black marketeers, mafia members, speculators and holders of 'dirty money' have benefited - especially if they openly and sufficiently loudly embraced the free-for-all form of parasitic capitalism.

Who is responsible? Who has so ruthlessly promoted these 'shock therapies' of governmental restrictions, dismantling of national economies, demise of autonomy and self-reliance, foreign sellouts, public auctions 'for cash' and wild speculations with hastily issued speculative paper? Who orchestrated these mass 'voucher' privatizations which have quickly become just an intermediate step before full foreign takeover and control? Is it all due to simple incompetence, misapplication of monetaristic doctrine and support of political strivings of power-hungry ex-communists? Is it due to petty immoralities of once-poor dissidents who cannot handle their unexpectedly abundant personal riches? Was it caused by those who uncritically supported the ex-communist 'shock-corps' from abroad?

The inexplicable arrogance and deep incomprehension of transformation processes by some Western media was exemplified by recent (New York Times, September 12, 1993) statement of a reporter: 'Her [i.e., prime minister Suchocka's] economic reforms have turned Poland into an Eastern European success story - but the populace isn't convinced'.

The populace is not convinced? Is not this 'populace' the only and primary purpose of any economic reform, anywhere? The populace of Russia is also not convinced. Can American people relate to this faceless statistical 'populace' of Poland? 
This 'populace', i.e., honestly working people and citizens of once proud Poland, now over $15 \%$ unemployed, remains rightfully unconvinced, disappointed or plain angry: only $20-25 \%$ are satisfied with the new system; 50-55\% are absolutely dissatisfied, according to official surveys.

The 'populace' of Russia is equally dissatisfied, especially after dismantling the remaining vestiges of democracy. But capitalism cannot be brought forth by decrees, censorship, guns or tanks - only socialism can.

The warnings were abundant and long available. The UN/ECE Economic Survey of Europe [1], released in April 1993, devoted an entire section, entitled 'The siren call of "shock therapy", to the failures of this unfortunate and theory-free metaphor or political expediency. The document states that if the metaphor of 'shock therapy' is taken literally, namely that it provides quick and lasting relief from a severe disorder, then 'the record is not a successful one, but clearly is too simple an approach which just shows up the limitations of the metaphor'.

This is true. Shock therapy has not been quick, radical or reliable, but protracted, chaotic, painful, unfair and with steadily diminishing prospects for any rebound. Can a four-year transition recession (like the one in former Czechoslovakia) still qualify as shock treatment? It clearly promises a more rapid adjustment than is possible and as a result must bear some responsibility for the current disappointment and disillusion in many of the transition economies. The UN Report continues:

'The argument, for example, that trade and price liberalization cannot be introduced gradually is simply not true. In Western Europe, wartime price and other controls were phased out in line with supplyside improvements so as to avoid setting off an inflationary spiral. The Western economies have also liberalized their international trade in a long, gradual process which began in 1947 and is still not complete.'

In contrast, most East European countries were forced to liberalize their trade and prices virtually overnight. The UN Survey:

'Those who advocate "shock therapy" appear to believe that it is possible to bring about a radical change in attitudes, expectations, and behaviour in a very short time. It is difficult to find much evidence for this.'

Evidence, no evidence - shock therapy is still being peddled by ex-communists and fellow travelers from abroad. The authors of the survey caution:

'Any large shock tends to increase (Keynesian) uncertainty and thus, to paralyze action and propagate wait-and-see attitudes.'

Elsewhere, the UN Survey offers observations that the post-socialist countries are not engaged only in creating market economies but also in building democratic institutions and developing democratic practices for the resolution of conflicting interests. This has been entirely forgotten and authoritarian forces are being propped up as the only alternative.

'Shock therapists' tend to ignore these questions: their approach tends, in effect if not by intention, to be autocratic and often arrogant in suggesting that 'there is no alternative' to their proposals.

On the contrary, there is always an alternative: that is what market economics and democratic politics are all about. So why is the West so enthusiastically supporting 'The Only Possible Way' and 'The Only Right Party' - i.e., socio-political aberrations which it would never tolerate in its own systems and institutions?

It is the job of the economic adviser to estimate the costs of the various alternatives so that responsible choices can be made by those who must either bear the costs directly or face the political consequences of underestimating them.

Yet, those who must bear the cost directly were never consulted, their worries and concerns never taken into account. They are the 'populace'.

Somewhat curiously, 'shock therapists' tend to be more worried about a reversion to the old command economy (as it would be possible), or a diversion to some 'third way' between the latter and the market (as there would be any), than the risk of losing popular support for the difficult transition to a market economy. 'This is surprising', the survey says, 'because the revolutions of 1989 in Eastern Europe and the rejection of the coup plotters in 1991 in Russia clearly demonstrated a massive disdain for the old regimes and a strong will for democracy and the market economy'.

True, but not so surprising. It is this very disdain 
for the old regimes which allows the shock therapists to crudely manipulate their citizenry and to show an even deeper disdain for their feelings. Whenever somebody disagrees, offers an alternative idea or proposes a discussion, it suffices to label him or her as 'desiring the return of the old regime' and both the person and the idea are done with. The tanks is the message.

The 'shock therapists' themselves are responsible for pushing their desperate and impoverished people back into the hands of ex-communist, fascist and leftist parties: they have discredited right-wing conservatism, free-market economics and democracy itself; they have discredited capitalism.

So-called post-communist or post-socialist societies still remain, decidedly and tragically, pre-capitalistic societies. The real economic reforms and societal transformations towards the real free markets and modern capitalism are still to occur.

The disillusionment and weakening support for the reforms reflect not so much a nostalgia for the past as disappointment at the level and duration of the costs of transition and, in particular, fear of unemployment and disquiet at what appears to be a highly uncertain future. Assorted 'belt tightenings', 'demand barriers' and 'temporary sacrifices' are theoretically inexplicable, practically cruel or suicidal and politically immoral: nobody has ever improved an economy by intentionally weakening it.

Ex-communists, criminals, profiteers and 'dirty money' had to act quickly: speed is essential to their survival. It is imperative that their money - and they are the only ones in Russia and Eastern Europe who could have accumulated any - finds its 'clean' and safe harbor as quickly as possible. That is why rapid price and trade liberalizations have figured so prominently in the reform programs recommended and adopted in these countries - because these are among the few reforms that can be implemented quickly.

'However, the results do not suggest that this was an obviously desirable step to have been taken', concludes the report. Indeed rapid price and trade liberalization may be destabilizing in a transition economy with inelastic supply responses (which are partly due to institutional rigidities) and with inadequate instruments and institutions for creating and maintaining macroeconomic stability.

Major part of transition reforms consists of in- stitutional and structural changes. This is not just a question of passing laws and creating new legal institutions but also developing the informal codes and standards of behavior, including managerial and business practices which underpin the working of all effective institutions. The institutional capital of a country also includes accumulation of skills and experience.

Transformation policies of ex-communists fly directly in the face of teachings of Von Hayek and Von Mises, the most fervent defenders of evolution, spontaneous social orders and adaptive institutionalization in economics. In fact the UN Report has noticed this anomaly:

'Economists of the Austrian School, most prominently Ludwig von Mises and Friedrich von Hayek, are nowadays frequently quoted to explain the failures of central planning in Eastern Europe and the former Soviet Union, but are rarely invoked when the transition process is being discussed. Not only did they emphasize the primordial importance of the institutional infrastructure for the effective operation of the market but they also stressed the fact of the evolutionary development of institutions and behavior over extended periods of time.

Those who believe that the former centrally planned economies can be "shocked" into market economies would appear to have overlooked some of the most fundamental requirement for a market economy to function effectively'.

In fact, Von Hayek's famous teachings on the primary role of knowledge and the need for enhancing and engaging local, decentralized knowledge among empowered, autonomous employees, have been programmatically ignored by the 'shock therapists' and any sort of employee empowerment, co-ownership or co-determination have been summarily dismissed.

Yet, a rapid change of ownership (mostly into public, not private hands) cannot automatically solve their problems or even assist in the creation of an efficient market economy. To sell such enterprises without first restructuring them (like in former Czechoslovakia) would undermine the creation of a competitive environment, although there are doubts that many of them would actually interest private buyers in their present state. Questions of competitive structure, effective corporate governance, etc., need to be settled before privatization 
takes place. Otherwise, the new private owners will probably resist any belated attempt to correct for market failures.

The extent of disillusionment and discontent continues to grow as the costs of adjustment have proved to be much greater than expected. Living standards are perceived to have fallen sharply for large strata of the citizenry. Growing resentment of this outcome is increased by the tendency of shock therapists, as well as many political leaders, to ignore the democratic requirement to explain and to allow time not only for discussion but also for people to adjust psychologically to the new orientations of economic and social policies.

The UN Survey also analyzes related political issues. In modern political economy the frustration of socially desirable reforms is most often explained by the potential losers, i.e., those with an interest in the status quo being able either to out-vote the potential gainers or to out-maneuver them through superior lobbying power. However, neither of these possibilities appears to fit the situation in transition economies. The status quo has already lost the vote in favor of reform. Those who did well under the old system appear to be doing even better under the new one. But if individuals are uncertain as to whether they will benefit from a reform, there may be a bias against the change even if it is certain that the majority will benefit. Individual uncertainty can therefore distort the aggregate vote: the majority might vote against itself.

There is already a widespread loss of patience with government leaders. In Poland, the elections showed preferences for former communists and other leftists - not because anybody wishes the return of communism, but because somebody has to clean up the mess left in the wake of the economic 'shock therapy'. In former Czechoslovakia, only $50 \%$ of the citizenry trust their own government. (President Havel's purchase of private villa for 40 million crowns or premier Klaus' insistence that he does not recognize 'dirty money' certainly do not help.) Russia needs no comment.

There is less willingness to take at face value the promises and predictions of policy-makers. The socalled 'voucher privatization' was based on public propaganda blitz promising over $1000 \%$ annual returns on investment! Western financial analysts and advisers supported this inept and cruel deceit.
The UN Survey warns that the governments of the transition economies are therefore unlikely to succeed by simply 'charging on'. Instead they will have to secure a large and broad-based measure of popular support if the transition to the market economy is to be achieved within the framework of democratic institutions.

One important step for Western and international donors would be to insist on discussing programs not only with governments but also with opposition parties and key social groups. None of such consultative dialogues is taking place: excessive confidentiality and government-to-government deals still prevail. No one has ever demonstrated that a lack of openness improves the quality of economic policy-making. Greater transparency is desirable within the transition countries, especially on issues such as privatization of state enterprises.

Shock-therapy-based transition remains directionless and chaotic. Rules and laws are being amended, changed or abandoned almost daily. No industrial policy, not even a transformation policy, exists in Russia or Eastern Europe. There is no focus on positive externalities which might encourage economic growth. Issues of business investment, public infrastructure investment, research and development, education and training have all been abandoned. Nothing to promote job creation, diffusion of new technologies and management techniques, opening of new markets, improve productivity or regenerate ecosystems has been done. All is being left to the 'blind forces of the market'. The whole idea of industrial policy is radically excised from all public discussions in Eastern Europe, although it continues to reign supreme in Japan, Germany and in the U.S.A. The development of regional partnerships between enterprises, business associations, and the local or regional governments is being sacrificed for capricious decrees and proclamations from the center.

What is emerging, amounts to a long-term trivialization of East European economies: they are becoming appendages, cheap-labor colonies, depressed regions of permanent dependency and underdevelopment, selling their best assets abroad, keeping the worst for themselves (distributing them free among the citizenry) and increasingly relying on raw materials, prostitution and tourism as sources of foreign currency. 
Instead of simply 'privatizing' existing assets which are very few, unproductive and with little prospects - one should grant to economic agents the right to accumulate their part in the creation of additional wealth. Instead of exchanging existing claims to limited wealth in secondary markets, one should finance new production and exchanges.

Production of new wealth is the necessary imperative. Redistribution of the old wealth is insufficient. Wage laborers and state managers have to become entrepreneurs, capitalists and co-owners, i.e., active market-making agents.

Privatization should not be conceived as a simple transfer of property rights from the state to public (or private) domains. Privatization must be conceived as a radical process of deconstruction of claims of power centers (state) to controlling the use, possession and disposal of productive assets. Property rights are not absolute powers of sovereign individuals or groups, as in medieval times, but modern business contracts. The right to ownership is a bundle of such rights and contracts.

Privatization (not the mass, voucher-based distribution) of the means of production remains the corner stone of any economic transformation. Privatization is and should be a matter of economic policy, not a half-baked political expediency.

IMF and World Bank experiences with privatizations in Latin America, Asia and Africa are quite irrelevant in Russia and Eastern Europe. Public-, state- and government-run companies in freemarket systems do not fundamentally differ from private companies. The difference is only a matter of degree in their efficiency and competitiveness. However, state-run (and even private) companies in Eastern Europe were integral part of central-command system and thus their structures, management and decision-making habits are fundamentally different.

It is doubtful that socialist companies are even 'companies' in the true sense of that word. They cannot be privatized until there is clear definition in terms of employers, employees, owners and governors. State-run companies in socialist countries cannot belong to the same category as publiclyowned companies in capitalistic systems. Without clear and long-term 'insider' ownership no meaningful restructuralization and rationalization of operations can take place.

It is useless and futile to 'privatize' without projecting the structure or design of the privatized company-to-be. Private 'mess' is still as much of a mess as a public mess.

Because of the imperative of restructuralization and rationalization, any wide distribution of shares to an unspecified portion of general public and any indefinitness of managerial responsibility should be avoided. Responsible and company-devoted management cannot grow out of public distribution of shares. Paper owners in Czech Republic (so called 'DIKs') do not and cannot behave in any other way than ordinary bondholders. To expect such people to provide the spirit of ownership that is the energy that drives companies forward is absolutely unrealistic.

The voucher method creates only the form of private ownership for individual (and public) control of the firm; it does not create private spirit of ownership as a necessary driving force. Even the threat of bankruptcy does not mobilize to action or company preservation, but only to quick reapportionment of the corporate 'carcass'. The threat of bankrupty in Czech enterprises has led perversely to increased wages and perks (including foreign automobiles), increased employment and falling productivity and production - all at the same time.

It is naive, idealistic and ideological when important economic concepts like planning, industrial policy, government intervention, independent supervision by workers and standards within factories are considered 'dirty words' in Eastern Europe. After chasing pure socialism or communism for most of the century, the current chase after 'pure capitalism' is clearly a 'genetic' behavioral trait of ex-communists. Yet, governments of Eastern Europe remain strangely passive: they do not construct any vision of the future while they continue feverishly dismantling the past.

The means (privatization, liberalization, etc.) have become the goals and purposes in themselves.

In the final analysis, only individuals and groups who are bound together by strong interests and identification with the company, only people who have cast their lives and lots with the company can bring forth responsible and effective management of an enterprise. Only company private owners and 
true 'insiders' (managers, employees, entrepreneurs) can turn things around - not the millions of public, passive and absent owner-speculators, socalled DIKs.

It is true that economic profession was caught by surprise and that no theories of transformation from socialism to capitalism were ever worked out. This theoretical vacuum opened the door and was quickly filled by the irrelevant experiences of IMF and World Bank and by irresponsible economists cum politicians who quickly exploited the situation.

Only recently, painfully and slowly, the theories of transformation started to emerge and serious economists offered their practical policy recom- mendations. This could be too little and too late for the people of Russia and Eastern Europe.

Milan ZELENY

Graduate School of Business

Fordham University at Lincoln Center

New York, NY 10023

U.S.A.

\section{References}

[1] UN/ECE Economic Survey of Europe Analyses Development of Transition Countries and Western Market Economies, Press release ECE/GEN/6, 1 April 1993. 